\begin{tabular}{|c|c|c|}
\hline \hline & $\begin{array}{c}\text { International Journal of Current Research in } \\
\text { Biosciences and Plant Biology }\end{array}$ \\
\hline EXCELLENT \\
PUBLISHERS
\end{tabular}

\title{
Wild Edible and Medicinal Plants Used by Apatani Community of Lower Subansiri District, Arunachal Pradesh, India
}

\author{
Bipul Ch. Kalita ${ }^{1}$, S.C. Arya ${ }^{2 *}$ and Hui Tag ${ }^{3}$ \\ ${ }^{1}$ Junior Research Fellow, G.B. Pant National Institute of Himalayan Environment \& Sustainable Development, North East Unit, \\ Vivek Vihar, Itanagar- 791 113, Arunachal Pradesh, India \\ ${ }^{2}$ Scientist 'C', G.B. Pant National Institute of Himalayan Environment \& Sustainable Development, North East Unit, Vivek Vihar, \\ Itanagar- 791 113, Arunachal Pradesh, India \\ ${ }^{3}$ Senior Assistant Professor, Department of Botany, Rajiv Gandhi University, Rono Hills- 791 112, Arunachal Pradesh, India
}

*Corresponding author.

\begin{abstract} the Apatani community.

\section{Introduction}

Arunachal Pradesh, the land of dawn lit mountains, lying in the eastern most tip of northeast India is uniquely situated in the transition zone between the Himalayan and Indo-Burmese regions $\left(26^{\circ} 28^{\prime}-29^{\circ} 30^{\prime}\right.$ $\mathrm{N}$ and $91^{\circ} 30^{\prime}-97^{\circ} 30^{\prime} \mathrm{E}$ ) covering an area of 83,743 $\mathrm{km}^{2}$. The people are predominantly tribal, with schedule tribes forming $65 \%$ of the population. There are 26 major tribes and more than 120 sub tribes, each with a specific geographic distribution and distinct linguistic, cultural and social identity. Most of the population is engaged in agriculture.
\end{abstract}

Arunachal Pradesh, a part of North East India known for its rich plant diversity and cultural diversity. It has been recognized as the 25 th biodiversity hotspot in the world. It is also among the 200 globally important ecoregion. The Lower Subansiri district of the state is well known for the unique tradition of wet rice cultivation. The district is dominated by the Apatani tribe. The use of plants in the form of medicine and other purposes is time immemorial especially the tribal people who are intimately connected with plant resources. The present study deals with some highly used wild edible and medicinal plant species including herbs, shrubs, climber and trees by the Apatani tribe of Lower Subansiri district, Arunachal Pradesh, which have been least explored in this region. Total 41 wild edibles and medicinal plant species have been recorded belonging to 33 families used by

\section{Article Info}

Accepted: 09 February 2017

Available Online: 06 March 2017

\section{Keywords}

Apatani community

Indigenous knowledge

Lower Subansiri District

Medicinal plants

Wild edible plants
Apatani community is one of the major indigenous communities of Arunachal Pradesh and known for its rich traditional and indigenous knowledge of natural resources management and conservation. They are predominantly found on Lower Subansiri district of Arunachal Pradesh covering an area of 1,317 Sq.km (Anonymous, 1992). The district is bounded on the North by China and Upper Subansiri District, on the South by Papum Pare District and Assam, on the East by West Siang and some part of Upper Subansiri and, on the West by East Kameng District of Arunachal Pradesh. On her Northeast, lies the Tirap District of Arunachal Pradesh. 
The study area is luxuriant in terms of edible and medicinal plants, used by the local people. But still this wealth is not fully explored and lots of species has to be identified and documented. Keeping in view the fact the present work was carried out in this area.

\section{Materials and methods}

\section{Study site}

The Lower Subansiri District covers approximately an area of 10,135 Sq.km. The topography of the District is mostly mountainous terrain, where the Hill Ranges varies approximately from 1000 to 1600 meters above sea level. The district headquarter is located at Ziro a small town at about 1564 meters above sea level (Fig. 1). The forests of the district are biodiversity rich with wide varieties of wild edible and medical plants in forms of herbs, shrubs, climbers and trees. The study was conducted in Ziro by randomly selected four village's viz. Lampia, Hari, Siro and Yazali of the Lower Subansiri district during the year 2013-2014.

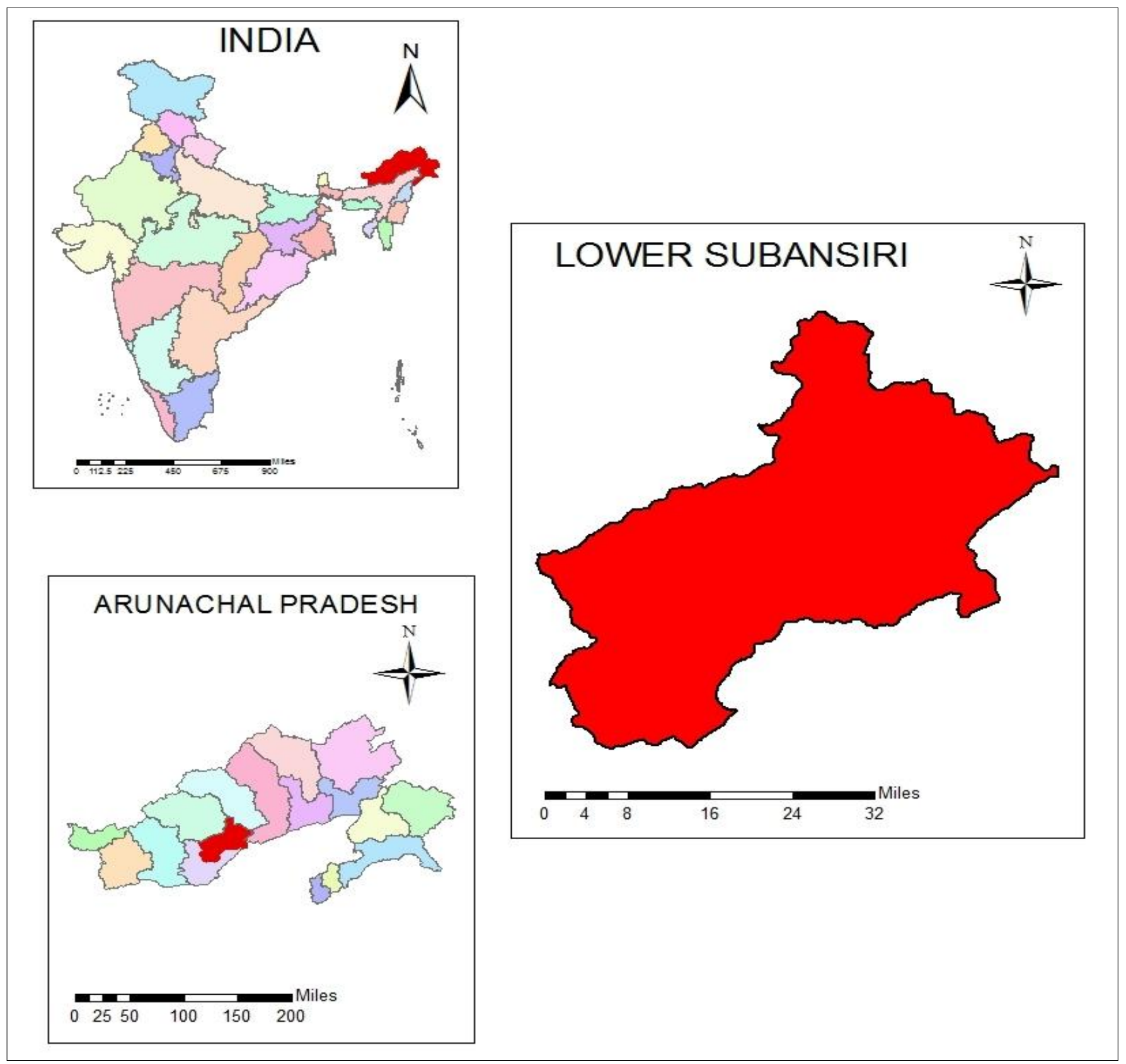

Fig. 1: Location map of the study area. 


\section{Data collection}

The data were collected through the informal interview and discussion with the local people particularly with traditional healers from each village. Among the village experts, one knowledgeable person was hired to survey and collect the plant species from wild habitats. Information on the local names, life forms, part(s) used and indigenous uses was gathered.

\section{Identification of plant species}

Identification of species was carried out with the help of taxonomic literature (Wu et al., 2003-2010; Hooker, 1872-1897; Hooker, 1888), Haridasan (19850), Kanjilal et al. (1934-40), Botanist and authentic herbarium specimens of Botanical Survey of India (ARUN), and SFRI (APFH), Itanagar, Arunachal Pradesh. The standard methodology of Jain and Rao (1978) and Jain (1991) had been followed during the herbarium preparation.

\section{Results and discussion}

Total 41 species of wild edible and medicinal plants (15 herbs, 3 shrubs, 5 climbers, 17 trees) belonging to 33 families have been recorded from the study site. Among all species 6 species represents both wild edible and medicinal (Tables 1 and 2; Figs. 3 and 4).
Considering the richness of the species, the family Combretaceae and Verbenaceae (4 species each) was the richest, followed by, Apiaceae, Clusiaceae, Euphorbiaceae, Lauraceae, Poaceae, Rubiaceae, Saururaceae and Zingiberaceae (2 species each). The rest of the families were represented by only single species (Tables 1 and 2; Fig. 2). The dominant genera were Terminalia (4 species), followed by Clerodendrum, Euphorbia, Garcinia, Houttuynia (2 species each) (Tables 1 and 2).

Fruits of 15 species, combination of different parts of 9 species, leaves of 7 species, whole plant of 3 species, young shoot of 3 species, bark of 2 species, rhizome of 2 species, stem of 2 species, flower of 1 species, root of 1 species, tuber of 1 species, and whole shoot of 1 species have been used for various purposes (Tables 1 and 2; Fig. 5).

These species are used as edible and to cure various diseases/ailments. For example Fruits of Terminalia bellirica are used for Diarrhea, piles and dropsy; leaves of Cinnammom tamala are used for Cough, headache and dizziness; boiled leaves of Plantago erosa are used to get relief from constipation; rhizome of Acorus calamus is used for cut, wounds and skin diseases; stem of Berberis aristata is used for cold, fever and malaria; rhizome of Costus speciosus is used for cough catarrhal, catarrhal fever, dyspepsia, skin diseases and worm infections (Tables 1 and 2).

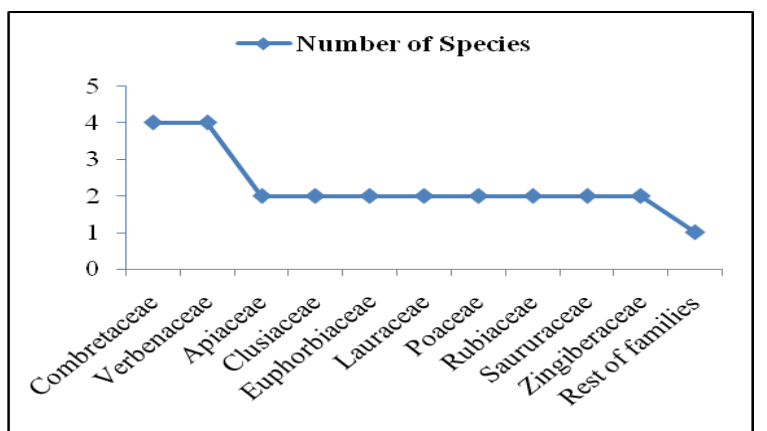

Fig. 2: Distribution of species among families.

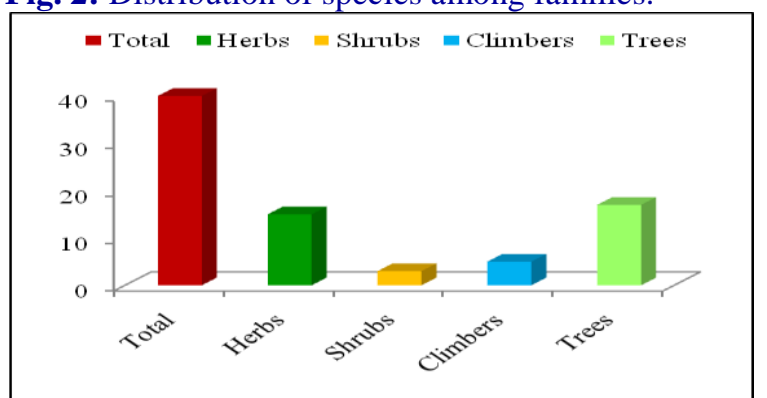

Fig. 4: Distribution of life forms among the species.

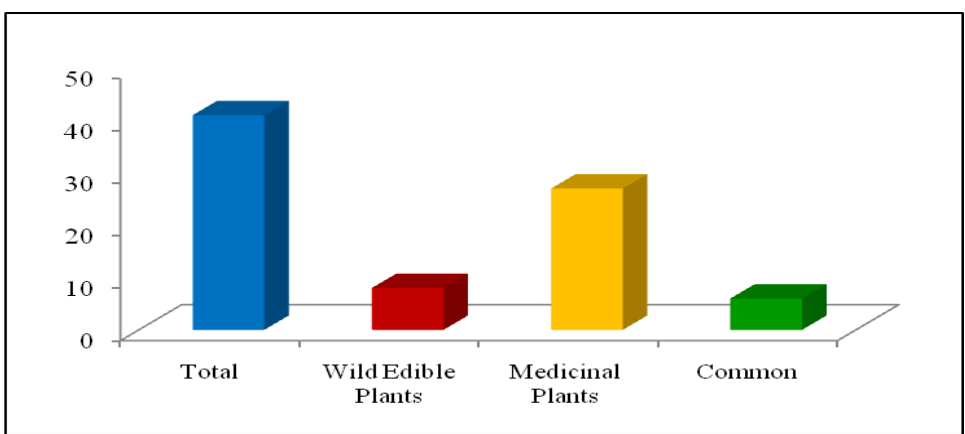

Fig. 3: Species richness of wild edibles and medicinal plants.

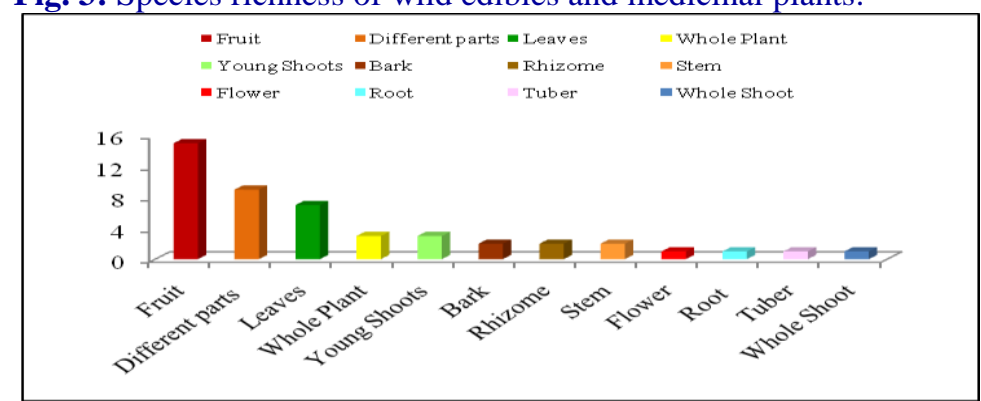

Fig. 5: Distribution of parts used among species. 
Table 1. Wild Edible Plants of the study area.

\begin{tabular}{|c|c|c|c|c|c|c|}
\hline S.N. & Species & Life form & Family & Local/Trade name & Part used & Uses \\
\hline 1. & Cephalostachyum capitatum Munro & Shrub & Poaceae & Yaiing Byapu & Young Shoots & $\begin{array}{l}\text { Young Shoots eaten as } \\
\text { vegetables }\end{array}$ \\
\hline 2. & $\begin{array}{l}\text { Clerodendrum } \\
\text { colebrookianum Walp. }\end{array}$ & Shrub & Verbenaceae & Pato & $\begin{array}{l}\text { Leaves, Seed, Flower, } \\
\text { Young Shoot }\end{array}$ & Leaves are taken as vegetables \\
\hline 3. & Euphorbia hirta L. & Herb & Euphorbiaceae & Yakap-talap & Tender Plant, Latex & Vegetables \\
\hline 4. & $\begin{array}{l}\text { Garcinia pedunculata Roxb. Ex Buch.- } \\
\text { Ham. }\end{array}$ & Tree & Clusiaceae & Mibia San & Fruit & Fruits are edible \\
\hline 5. & Houttuynia cordata Thunb. & Herb & Saururaceae & Amuli, Hanya & $\begin{array}{l}\text { Leaves, Rhizome, } \\
\text { Whole Plant, Shoots }\end{array}$ & Whole plant edible \\
\hline 6. & Hydrocotyle sibthorpioides $\mathrm{L}$. & Herb & Araliaceae & $\begin{array}{l}\text { Manni Ao, Ajone, } \\
\text { Manimuni }\end{array}$ & Leaves & Leaves are taken as vegetables \\
\hline 7. & Michelia champaca L. & Tree & Magnoliaceae & Salyo & Whole Fruit & $\begin{array}{l}\text { Seeds are taken for stomach ache } \\
\text { and as an appetizer }\end{array}$ \\
\hline 8. & Myrica esculenta Buch.-Ham. ex D. Don & Tree & Myricaceae & Baching & Fleshy part of the Fruit & Fruits are edible \\
\hline 9. & $\begin{array}{l}\text { Phyllostachys bambusoides Siebold \& } \\
\text { Zucc. }\end{array}$ & Herb & Poaceae & Bije Byapu & Young Shoots & $\begin{array}{l}\text { Young Shoots eaten as } \\
\text { vegetables }\end{array}$ \\
\hline 10. & Plantago erosa Wall. & Herb & Plantaginaceae & Nidomarto & Leaves & $\begin{array}{l}\text { Boiled leaves are taken to get } \\
\text { relief from constipation }\end{array}$ \\
\hline 11. & Solanum indicum $\mathrm{L}$. & Herb & Solanaceae & Bake & Fruit & Fruits are eaten \\
\hline 12. & Spondias axillaris Roxb & Tree & Anacardiaceae & Biiling & Fleshy part of the Fruit & Fruits are edible \\
\hline 13. & Terminalia bellirica (Gaertn.) Roxb. & Tree & Combretaceae & Bhumura & Fleshy part of the Fruit & Fruits are edible \\
\hline 14. & Terminalia chebula Retz. & Tree & Combretaceae & Samper & Fleshy part of the Fruit & Fruits are edible \\
\hline
\end{tabular}


Table 2. Medicinal plants of the study area.

\begin{tabular}{|c|c|c|c|c|c|c|}
\hline S.N. & Species & Life form & Family & Local/Trade Name & Parts used & Uses \\
\hline 1. & Achyranthes aspera $\mathrm{L}$. & Herb & Amaranthaceae & Devil Horsewhip & Whole plant & Skin injuries and wound healing \\
\hline 2. & Acorus calamus L. & Herb & Acoraceae & Bach & Rhizome & Cut, wounds, skin diseases \\
\hline 3. & Alpinia nigra (Gaertner) B. L. Burtt & Herb & Zingiberaceae & Tara & Root & Dyspepsia \\
\hline 4. & $\begin{array}{l}\text { Andrographis paniculata (Burm.f.) } \\
\text { Nees }\end{array}$ & Herb & Acanthaceae & Kalmegh & Whole shoot & Intestinal worms, skin diseases \\
\hline 5. & Argeria nervosa (Burm.f.) Bojer & Climber & Convolvulaceae & Elephant Creeper & Leaves & $\begin{array}{l}\text { Eczema, chronic ulcers and skin } \\
\text { disease }\end{array}$ \\
\hline 6. & Berberis aristata DC. & Shrub & Berberidaceae & Chitrak, Indian Berry & Stem & Cold, fever, malaria \\
\hline 7. & Callicarpa arborea Roxb. & Tree & Lamiaceae & Yoh Sen & Bark & Fiver, gastric and headache \\
\hline 8. & Canarium strictum Roxb. & Tree & Burseraceae & Dhuna, Sulum Sen & Resin, bark & Rheumatic pain and skin diseases \\
\hline 9. & Centella asiatica (L.) Urb. & Herb & Apiaceae & Gotula, Manimuni & Leaves/Shoot & $\begin{array}{l}\text { Constipation, gastritis, blood } \\
\text { purification }\end{array}$ \\
\hline 10. & $\begin{array}{c}\text { Cinammom tamala (Buch.-Ham.) } \\
\text { T.Nees \& C.H.Eberm. }\end{array}$ & Tree & Lauraceae & Tejpatta & Leaves & Cough headache and dizziness \\
\hline 11. & $\begin{array}{l}\text { Clerodendrum colebrookianum } \\
\text { Walp. }\end{array}$ & Shrub & Verbanaceae & Poto Sen & Leaves & $\begin{array}{l}\text { Hypertension, cough, asthma skin } \\
\text { diseases and dysentery }\end{array}$ \\
\hline 12. & Costus speciosus (J.Koenig) Sm. & Herb & Costaceae & Jom Lakhuti & Rhizome & $\begin{array}{l}\text { Cough, fever, dyspepsia, skin } \\
\text { diseases and worm infections }\end{array}$ \\
\hline 13. & Dioscore aalata L. & Climber & Dioscoreaceae & Kathalu & Tuber & Anthelminthic, leprosy and piles \\
\hline 14. & $\begin{array}{l}\text { Drymaria cordata (L.) Willd. ex } \\
\text { Schult. }\end{array}$ & Herb & Caryophyllaceae & - & Leaves & Diarrhea, cough, headache \\
\hline 15. & Eclipta alba (L.) Hassk. & Herb & Asteraceae & Tosum Dumpi & Whole plant & $\begin{array}{l}\text { Hepatic, spleen enlargement and } \\
\text { skin diseases }\end{array}$ \\
\hline 16. & Euphorbia hirta L. & Herb & Euphorbiaceae & Snake Weed & Whole plant & Dysentery \\
\hline
\end{tabular}




\begin{tabular}{|c|c|c|c|c|c|c|}
\hline S.N. & Species & Life form & Family & Local/Trade Name & Parts used & Uses \\
\hline 17. & $\begin{array}{l}\text { Garcinia pedunculata Roxb. ex } \\
\text { Buch.-Ham. }\end{array}$ & Tree & Clusiaceae & Bortheakera & Fruit & Diarrhea and dysentery \\
\hline 18. & Gmelina arborea Roxb. & Tree & Lamiaceae & Gamari & Bark, fruit & Fever, asthma, tonic \\
\hline 19. & Gynocardia odorata R.Br. & Tree & Achariaceae & Baa, Chalm & Fruit & Leprosy and skin diseases \\
\hline 20. & Houttuynia cordata Thunb & Herb & Saururaceae & Mosondori & Leaves & $\begin{array}{l}\text { Skin trouble, stomachache, cholera } \\
\text { and dysentery, tonic }\end{array}$ \\
\hline 21. & $\begin{array}{l}\text { Illicium griffithii Hook.f. \& } \\
\text { Thomson }\end{array}$ & Tree & Schisandraceae & Lyssi & Fruit & Stimulant and carminative \\
\hline 22. & Litsea cubeba (Lour.) Pers. & Tree & Lauraceae & Tayir Sen & Fruit & Hysteria, paralysis, dizziness \\
\hline 23. & Lycopodium clavatum $\mathrm{L}$. & Herb & Lycopodiaceae & Launha & Young shoot & Gall Bladder \\
\hline 24. & Oroxylum indicum (L.) Kurz & Tree & Bignoniaceae & Bhatgila & Bark, flower & $\begin{array}{l}\text { Dysentery, diarrhea and } \\
\text { stomachache }\end{array}$ \\
\hline 25. & $\begin{array}{l}\text { Paederia foetidavar. Microcarpa } \\
\text { Kurz }\end{array}$ & Climber & Rubiaceae & Bhadai Lota & Leaves/Shoot & Headache and piles \\
\hline 26. & $\begin{array}{l}\text { Piper mullesua } \\
\text { Buch.-Ham. ex D. }\end{array}$ & Shrub & Piperaceae & Pipli & Fruit & Digestive, constipation \\
\hline 27. & Rhododendron arboretum $\mathrm{Sm}$. & Tree & Ericaceae & Bruan & Flower & Cough, diarrhea and dysentery \\
\hline 28. & Rubia manjith Roxb. ex Fleming & Climber & Rubiaceae & Tamen & Stem & Diarrhea, dysentery \\
\hline 29. & Syzigium cumini $\mathrm{L}$. & Tree & Myrtaceae & Jamun & Fruit & Antidiabetic, asthma and antipyretic \\
\hline 30. & Taxus wallichiana Zucc. & Tree & Taxaceae & Himalayan Yew & Bark & Stomachache \\
\hline 31. & Terminalia bellirica (Gaertn.) Roxb. & Tree & Combretaceae & Bohera, Beddas Nut & Fruit & Diarrhea, piles, dropsy \\
\hline 32. & Terminalia chebula Retz. & Tree & Combretaceae & Hilika, Harar & Fruit & Tonic, refreshing \\
\hline 33. & Tinospora cordifolia (Willd.) Miers & Climber & Menispermaceae & Amrit Lata & $\begin{array}{l}\text { Stem, Root, } \\
\text { Leaves }\end{array}$ & Fever and Dyspepsia \\
\hline
\end{tabular}




\section{Conclusion}

The results of the present study indicate that the area is rich in medicinal and wild edible plants. The local communities have maintaining the rich indigenous knowledge about the uses of plants for the medicinal and other purposes. This wealth needs immediate action for the conservation and management. Moreover, some medicinal plants have high market values. The national and international marketing potentiality of these species needs immediate assessment of wild edibles and medicinal plants in such biodiversity rich areas. The rare indigenous knowledge about the medical plants has to be preserved. It may be concluded that the present study has made an important contribution towards the documentation, conservation and management of wild edibles and medicinal plants of Lower Subansiri district in particular and Arunachal Himalayan Region in general.

\section{Conflict of interest statement}

Authors declare that they have no conflict of interest.

\section{Acknowledgement}

The authors are thankful to Director, G.B. Pant National Institute of Himalayan Environment and Sustainable Development, Kosi-Katarmal, Almora, Uttarakhand for facilities and encouragement. Help received from Mrs. Pallabi K. Hui and Mr. Debmalya Dasgupta is highly acknowledged. The authors are highly thankful to the villagers of Ziro valley for sharing valuable information and support during the field study.

\section{References}

Anonymous, 1992. The Wealth of India. A Dictionary of Indian Raw materials and Industrial products, III Publications and Information Directorate, New Delhi. pp.582-590.

Haridasan, K., 1985. Botanical and Vernacular names of Important and Common Forest Plants of Arunachal Pradesh. Forest Bulletin No.3. Forest Department, Government of Arunachal Pradesh.

Hooker, J.D., 1872-1897. The Flora of British India. 1-7. L. Reeve \& Co., London.

Hooker, J.D., 1888. The Flora of British India. 5, 477544. L. Reeve \& Co., London.

Jain, S.K., Rao, R.R., 1978. A Hand Book of Field and Herbarium Method. BSMPS, New Delhi, India.

Jain, S.K., 1991. Dictionary of Indian Folk Medicine and Ethnobotany (A reference Manual of ManPlant Relationships, Ethnic Groups \& Ethnobotanist in India). Deep Publications, New Delhi.

Kanjilal, U.N., Das, A., Kanjilal, P.C., De, R.N., 193440. Flora of Assam Vol. I-IV. (Repr. 1984), Under the Authority of Government of Assam.

Wu, Z.Y., Raven, P.H., Hong, D.Y., 2003-10. Flora of China. Vol. 7-13. Science Press, Beijing and Missouri Botanical Garden Press, St. Louis.

\section{How to cite this article:}

Kalita, B. Ch., Arya, S.C., Tag, H., 2017. Wild edible and medicinal plants used by Apatani community of Lower Subansiri District, Arunachal Pradesh, India. Int. J. Curr. Res. Biosci. Plant Biol. 4(3), 64-70.

doi: https://doi.org/10.20546/ijcrbp.2017.403.007 